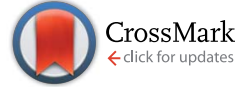

Cite this: RSC Adv., 2017, 7, 1490

Received 15th November 2016 Accepted 1st December 2016

DOI: 10.1039/c6ra26806d

www.rsc.org/advances

\section{Removal of trace arsenic to below drinking water standards using a $\mathrm{Mn}-\mathrm{Fe}$ binary oxide}

\author{
Jiefei Li, ${ }^{a}$ Hiroki Gyoten, ${ }^{b}$ Akinari Sonoda, ${ }^{c}$ Qi Feng ${ }^{b}$ and Mei Xue ${ }^{* a}$
}

A series of $\mathrm{Mn}$-Fe binary oxides with different $\mathrm{Mn} / \mathrm{Fe}$ mole ratios were prepared by a co-precipitation method for the development of a high performance arsenic adsorbent from arsenic-contaminated drinking water. The $\mathrm{Mn}-\mathrm{Fe}$ binary oxides and their arsenic adsorption reactions were characterized by $\mathrm{X}$ ray powder diffraction, Fourier transform infrared spectroscopy, scanning electron microscopy, $\mathrm{N}_{2}$ adsorption and inductively coupled plasma mass spectrometry. The As(III) and As(V) adsorption results reveal that the arsenic adsorption ability is strongly dependent on the $\mathrm{Mn} / \mathrm{Fe}$ mole ratio and surface area of the adsorbent. The MF4/6-10 $\left(\mathrm{H}_{2} \mathrm{O}_{2}\right)$ sample which was prepared by alkaline solution containing $\mathrm{H}_{2} \mathrm{O}_{2}$ shows the excellent arsenic removal of $99.9 \%$, reducing As(III) concentration from $2 \mathrm{mg} \mathrm{g}^{-1}$ to $2 \mu \mathrm{g} \mathrm{L}^{-1}$, which can clear the new arsenic limit of $10 \mu \mathrm{g} \mathrm{L}^{-1}$ in drinking water by the WHO. Manganese species in the adsorbent accelerates oxidation of As(III) to As(v), which enhances the As(III) adsorption ability of the adsorbent. Meanwhile, iron species in the adsorbent have a role to form surface $\mathrm{OH}$ groups, which is an important factor for the effective adsorption of $\mathrm{As}(\mathrm{v})$ by a surface chelating reaction.

\section{Introduction}

Common arsenic species in the environment include arsenate (As(v)), arsenite (As(III)), dimethylarsenic acid and monomethylarsenic acid. In natural water, arsenic presents primarily in inorganic forms which are more toxic than the organic forms..$^{1-3}$ Arsenic contamination in ground water is creating serious environmental problems. As(III), which is more toxic than $\mathrm{As}(\mathrm{v})$, is the dominant arsenic in ground water..$^{4-6}$ Long-term uptake of arsenic-contaminated drinking water has negative impacts on human health., ${ }^{7,8}$ About 125 million people in Bangladesh have been estimated to be adversely affected by arseniccontaminated drinking water. ${ }^{9}$ In order to minimize these health risks, the WHO and the U.S. Environmental protection agency has revised the maximum contaminant level of arsenic in drinking water from $50 \mu \mathrm{g} \mathrm{L}^{-1}$ down to $10 \mu \mathrm{g} \mathrm{L}^{-1}$, and this new limit of $10 \mu \mathrm{g} \mathrm{L}^{-1}$ has become effective since January 2006 . $^{\mathbf{1 0}}$

Many methods such as coagulation/precipitation, ion exchange, membrane filtration, adsorption, reverse osmosis and electrocoagulation process had been used for arsenic removal. ${ }^{11-17}$ In these methods, arsenic adsorption removal is considered to be one of the most promising technologies because it is effective in the removal of low-concentration

${ }^{a}$ School of Chemistry and Chemical Engineering, Inner Mongolia University, 235 West University Road, Hohhot, 010021, China. E-mail: setsubai@sina.cn; Fax: +86-4714992981

${ }^{b}$ Department of Advanced Materials Science, Faculty of Engineering, Kagawa University, 2217-20 Hayashi, Takamatsu, 761-0396, Japan

${ }^{c}$ Health Technology Research Center, National Institute of Advanced Industrial Science and Technology (AIST), 2217-14 Hayashi, Takamatsu, 761-0395, Japan arsenic from liquids. ${ }^{16-21}$ Up to now, several adsorbents have been reported by some studies, and the results suggest that amorphous hydrous ferric oxide, poorly crystalline hydrous ferric oxide and goethite have high arsenic adsorption ability. ${ }^{16,22} \mathrm{Gu}$ et al. have prepared granular activated carbonbased iron-containing adsorbents in which the impregnated hydrous ferric oxide is amorphous form which could remove arsenic most efficiently. ${ }^{23}$ Jang et al. have used hydrous ferric oxide incorporated into diatomite adsorbent for arsenic column application. The adsorbent shows higher arsenic adsorption ability and adsorption capacity compared to AAFS-50 adsorbent (activated alumina that is used as arsenic removal adsorbent in Bangladesh). ${ }^{24,25}$ Oscarson et al. prepared $\mathrm{Fe}_{2} \mathrm{O}_{3}$-coated $\mathrm{MnO}_{2}$ adsorbent to reduce As(III) concentration by oxidizing it to As(v) under adsorption conditions. $\mathrm{MnO}_{2}$ (birnessite) is a very effective oxidant and it can oxidize the As(III) to $\mathrm{As}(\mathrm{v})$, while $\mathrm{Fe}_{2} \mathrm{O}_{3}$ cannot convert $\mathrm{As}(\mathrm{III})$ to $\mathrm{As}(\mathrm{v})$ within $72 \mathrm{~h}^{26}$ Above studies demonstrated that the iron oxide or/and manganese oxide have a strong affinity for arsenic adsorption. Recently, a series of $\mathrm{Fe}-$ Mn binary oxide with different $\mathrm{Mn} / \mathrm{Fe}$ ratio were synthesized by co-precipitation method using potassium permanganate, iron sulfate heptahydrate and $\mathrm{NaOH}$ at $\mathrm{pH}$ of 7 and 8. As(III) oxidation and sorption are affected by $\mathrm{Mn} / \mathrm{Fe}$ ratio of the binary oxide. The adsorbents with $\mathrm{Mn} / \mathrm{Fe}$ ratio of $1: 3$ and $1: 6$ show maximum As(III) and As(v) uptake of $114 \mathrm{mg} \mathrm{g}^{-1}$ and $60 \mathrm{mg} \mathrm{g}^{-1}$, respectively. ${ }^{27}$ However, until now the optimum conditions for the preparation of $\mathrm{Mn}$-Fe binary oxide adsorbents are unclear.

Herein, we report the preparation condition of a high performance $\mathrm{Mn}$-Fe binary oxide adsorbent, and the influence of preparation conditions on its arsenic removal ability, 
including alkaline component and $\mathrm{pH}$ of reaction solutions, $\mathrm{Mn} / \mathrm{Fe}$ mole ratio and calcination treatment conditions. After the optimization of preparation conditions, the As(III) concentration in drinking water can be reduced from $2 \mathrm{mg} \mathrm{L}^{-1}$ to $2 \mu \mathrm{g}$ $\mathrm{L}^{-1}$ using this adsorbent.

\section{Experimental}

\section{Preparation of adsorbents}

Mn-Fe binary oxide was prepared by co-precipitation method. Manganese nitrate $\left(\mathrm{Mn}\left(\mathrm{NO}_{3}\right)_{2}, 1 \mathrm{~mol} \mathrm{~L}^{-1}\right)$ and iron nitrate $\left(\mathrm{Fe}\left(\mathrm{NO}_{3}\right)_{3}, 1 \mathrm{~mol} \mathrm{~L}^{-1}\right)$ solutions were mixed at a desired $\mathrm{Mn} / \mathrm{Fe}$ mole ratio of $10 / 0,8 / 2,6 / 4,4 / 6,2 / 8$, or $0 / 10$ (total volume: 20 $\mathrm{mL}$ ), and then deionized water was added to a final volume of $100 \mathrm{~mL}$. Desired amount of $\mathrm{NaOH}$ was dissolved in $200 \mathrm{~mL}$ of water to make an alkaline solution. The alkaline solution was added into the metal nitrate solution under vigorously stirring condition, after which the stirring was continued for $5 \mathrm{~min}$ and aged for $12 \mathrm{~h}$. The obtained suspension was separated and washed 3 times with deionized water by centrifugation (7000 rpm, $10 \mathrm{~min}$ ) and dried at $40{ }^{\circ} \mathrm{C}$. The adsorbents are designated as MFX- $Y$, where MF expresses Mn and Fe, $X$ corresponds to the mole ratio of starting $\mathrm{Mn} / \mathrm{Fe}$ mole ratio, and $Y$ the $\mathrm{pH}$ value of the reacting solution.

Another series of Mn-Fe binary oxide was prepared using an alkaline solution $(200 \mathrm{~mL})$ containing $3 \% \mathrm{H}_{2} \mathrm{O}_{2}\left(\mathrm{H}_{2} \mathrm{O}_{2}\right.$ acts as oxidizing agent). The preparation procedure was the same as above. The adsorbents obtained are designated as MFX$Y\left(\mathrm{H}_{2} \mathrm{O}_{2}\right)$, etc., similar to those obtained without $\mathrm{H}_{2} \mathrm{O}_{2}$.

Low-crystalline akaganeite $(\beta-\mathrm{FeOOH})$, high crystalline akaganeite, and schwertmannite were prepared for the comparison of their arsenic adsorption abilities. Low-crystalline akaganeite was obtained by the hydrolysis of $\mathrm{FeCl}_{3}$ at $\mathrm{pH}=10$ and highcrystalline akaganeite by the hydrothermal treatment of ureacontaining $\mathrm{FeCl}_{3}$ solution at $100{ }^{\circ} \mathrm{C} .{ }^{28,29}$ Schwertmannite was prepared by hydrolysis of $\mathrm{FeCl}_{3}$ in a solution containing $\mathrm{Na}_{2} \mathrm{SO}_{4}$ at $60{ }^{\circ} \mathrm{C} .{ }^{30}$

\section{Adsorption experiments}

Adsorption experiments were performed by a batch method. All chemicals were of analytical grade and were purchased from Kanto Chemical Co., Inc. (Osaka, Japan). The As(III) and As(v) solutions were prepared by diluting arsenic standard solutions of $100 \mathrm{mg} \mathrm{L}{ }^{-1} \mathrm{As}(\mathrm{III})\left(\mathrm{As}_{2} \mathrm{O}_{3}\right.$ in $0.005 \% \mathrm{HCl}$ solution) and $1000 \mathrm{mg} \mathrm{L}^{-1} \mathrm{As}(\mathrm{v})\left(\mathrm{As}_{2} \mathrm{O}_{5}\right.$ in $0.0005 \% \mathrm{HCl}$ solution) with ultrapure water, respectively. The arsenic adsorption from a diluted solution was carried out by adding the adsorbent $(25 \mathrm{mg}$ ) into the As(III) or As(v) solution (100 mL) and stirring for $22 \mathrm{~h}$ at room temperature. After the arsenic adsorption, the arsenic concentration of the supernatant solution was analyzed using a Seiko inductively coupled plasma mass spectrometer (ICP-MS SPQ9000) in [As] $<2 \mathrm{mg} \mathrm{L}^{-1}$ concentration range, or a Seiko inductively coupled plasma atomic emission spectrometer (ICPAES SPQ7800) in [As] $\geqq 2 \mathrm{mg} \mathrm{L}^{-1}$ concentration range. Adsorption isotherm was obtained by using solutions containing 10-20 mg L $\mathrm{L}^{-1} \mathrm{As}(\mathrm{III})$ or $\mathrm{As}(\mathrm{v})$.

\section{Characterization of adsorbent}

The crystal phase of the adsorbent was characterized using a powder X-ray diffractometer (XRD) (Rigaku type RINT2100) with $\operatorname{CuK} \alpha(\lambda=0.15418 \mathrm{~nm})$ radiation. BET surface area was calculated from a nitrogen adsorption isotherm (obtained on a Quantachrome-type 1-C apparatus) for adsorbent degassed at $120{ }^{\circ} \mathrm{C}$ for $2 \mathrm{~h}$. The particle size and morphology of the adsorbent were observed using field-emission scanning electron microscopy (FE-SEM) (JEOL, JSM-6700FZ). Fourier transform infrared (FT-IR) spectra were obtained by $\mathrm{KBr}$ method on a Perkin-Elmer Infrared spectrometer (2000 series).

The Fe and Mn contents of the adsorbent were determined by ICP-AES spectrophotometry after the sample was dissolved in a $5 \mathrm{M} \mathrm{HCl}$ solution containing $\mathrm{H}_{2} \mathrm{O}_{2}$. The $\mathrm{Mn}$ valence in the adsorbent was determined by redox titration. An adsorbent (0.1 g) was dissolved in a mixed solution of $\mathrm{Na}_{2} \mathrm{C}_{2} \mathrm{O}_{4}\left(0.150 \mathrm{~mol} \mathrm{~L}^{-1}\right.$, $10 \mathrm{~mL}), \mathrm{H}_{2} \mathrm{SO}_{4}(20 \% \mathrm{v} / \mathrm{v}, 10 \mathrm{~mL})$ and $\mathrm{H}_{2} \mathrm{O}(100 \mathrm{~mL})$, and heated at $70{ }^{\circ} \mathrm{C}$. The concentration of residual $\mathrm{C}_{2} \mathrm{O}_{4}{ }^{2-}$ ions was determined by titration with $\mathrm{KMnO}_{4}\left(0.020 \mathrm{~mol} \mathrm{~L}^{-1}\right)$ at around $70{ }^{\circ} \mathrm{C}$. The active oxygen content can be calculated by eqn (1)

$$
\begin{aligned}
& \text { Active oxygen content }(\mathrm{mmol} \mathrm{g} \\
& \\
& \quad=\left[C_{\mathrm{Na}_{2} \mathrm{C}_{2} \mathrm{O}_{4}} V_{\mathrm{Na}_{2} \mathrm{C}_{2} \mathrm{O}_{4}}-C_{\mathrm{KMnO}_{4}} V_{\mathrm{KMnO}_{4}} \times 5 / 2\right] /(2 \times W)
\end{aligned}
$$

where $C$ : concentration of $\mathrm{Na}_{2} \mathrm{C}_{2} \mathrm{O}_{4}$ or $\mathrm{KMnO}_{4}\left(\mathrm{~mol} \mathrm{~L}{ }^{-1}\right), V$ : volume of $\mathrm{Na}_{2} \mathrm{C}_{2} \mathrm{O}_{4}$ or $\mathrm{KMnO}_{4}(\mathrm{~mL}), W$ : weight of adsorbent $(\mathrm{g})$. The mean valence of $\mathrm{Mn}$ was calculated using the active oxygen content and Mn content. ${ }^{31}$

\section{Result and discussions}

\section{Synthesis and characterization of Mn-Fe binary oxide adsorbent}

Since $\mathrm{Mn}$ (II) ions precipitate effectively in a highly alkaline condition in the absence of oxidizing agent, we precipitated the binary oxides at $\mathrm{pH} 12$, changing the starting $\mathrm{Mn} / \mathrm{Fe}$ mole ratio $(10 / 0,8 / 2,6 / 4,4 / 6,2 / 8$ and $0 / 10)$. The synthesis conditions and composition analysis results of the adsorbents are shown in Table 1 . The Mn/Fe mole ratios of the adsorbents well correlate with that of the starting solutions, suggesting that both $\mathrm{Fe}(\mathrm{III})$ and $\mathrm{Mn}$ (II) ions are effectively precipitated at $\mathrm{pH} 12$. The Mn valence $\left(\mathrm{Z}_{\mathrm{Mn}}\right)$ shows a unique tendency to increase with a decrease of $\mathrm{Mn}$ content. This result reveals that Fe(III) promotes the oxidation of $\mathrm{Mn}$ (II) to $\mathrm{Mn}$ (Iv) in the co-precipitation reaction. The XRD patterns prepared adsorbents are shown in Fig. 1. $\mathrm{A} \mathrm{Mn}_{3} \mathrm{O}_{4}$ phase (JCPDF 24-0734) is formed in a $\mathrm{Mn} / \mathrm{Fe}$ mole ratio range of 10/0 to $6 / 4$, and its crystallinity decreases with reducing $\mathrm{Mn} / \mathrm{Fe}$ mole ratio. An $\alpha$-FeOOH phase (JCPDF 29-0713) is formed at $\mathrm{Mn} / \mathrm{Fe}=$ $0 / 10$. At $\mathrm{Mn} / \mathrm{Fe}=2 / 8$ and $4 / 6$, the samples show XRD patterns of nearly amorphous phase. The XRD result suggests that these binary oxide samples are not a simple mixture of $\mathrm{Mn}_{3} \mathrm{O}_{4}$ and $\alpha$ $\mathrm{FeOOH}$ crystals, but $\mathrm{Mn}$ and $\mathrm{Fe}$ are connected by a random network of $\mathrm{Fe}-\mathrm{O}$ and $\mathrm{Mn}-\mathrm{O}$ bonds to form amorphous phase.

These samples have large BET specific surface areas, and they keep the large surface areas even after heat treatment at $350{ }^{\circ} \mathrm{C}$ (Table 1). FE-SEM images of the adsorbents are shown in Fig. 2. Sample MF10/0-12 with $\mathrm{Mn}_{3} \mathrm{O}_{4}$ phase mainly consists of 
Table 1 Preparation conditions and properties of $\mathrm{Mn}$-Fe binary oxides prepared using $\mathrm{NaOH}$ solution at $\mathrm{pH} 12$

\begin{tabular}{|c|c|c|c|c|c|c|c|}
\hline \multirow[b]{2}{*}{ Adsorbent } & \multicolumn{2}{|c|}{ Preparation conditions } & \multicolumn{5}{|c|}{ Properties of adsorbent } \\
\hline & $\mathrm{Mn} / \mathrm{Fe}$ mole ratio & $\begin{array}{l}\text { Precipitation } \\
\mathrm{pH}\end{array}$ & $\mathrm{Mn} / \mathrm{Fe}$ mole ratio & $\mathrm{Z}_{\mathrm{Mn}}{ }^{a}$ & $S_{\mathrm{BET}}^{b}\left(\mathrm{~m}^{2} \mathrm{~g}^{-1}\right)$ & Crystal phase & $S_{\mathrm{BET}}(350)^{d}\left(\mathrm{~m}^{2} \mathrm{~g}^{-1}\right)$ \\
\hline MF10/0-12 & 1 & 12 & - & - & 23 & $\mathrm{Mn}_{3} \mathrm{O}_{4}$ & 15 \\
\hline MF8/2-12 & 4 & 12 & 4.18 & 3.01 & 136 & $\mathrm{Mn}_{3} \mathrm{O}_{4}$ & 99 \\
\hline MF6/4-12 & 1.5 & 12 & 1.60 & 3.09 & 255 & $\mathrm{Mn}_{3} \mathrm{O}_{4}$ & 161 \\
\hline MF0/10-12 & 0 & 12 & - & - & 166 & $\alpha-\mathrm{FeOOH}$ & 68 \\
\hline
\end{tabular}

${ }^{a}$ Mean valence of manganese. ${ }^{b}$ BET surface area. ${ }^{c}$ Amorphous phase. ${ }^{d}$ BET surface area after calcination at $350{ }^{\circ} \mathrm{C}$.

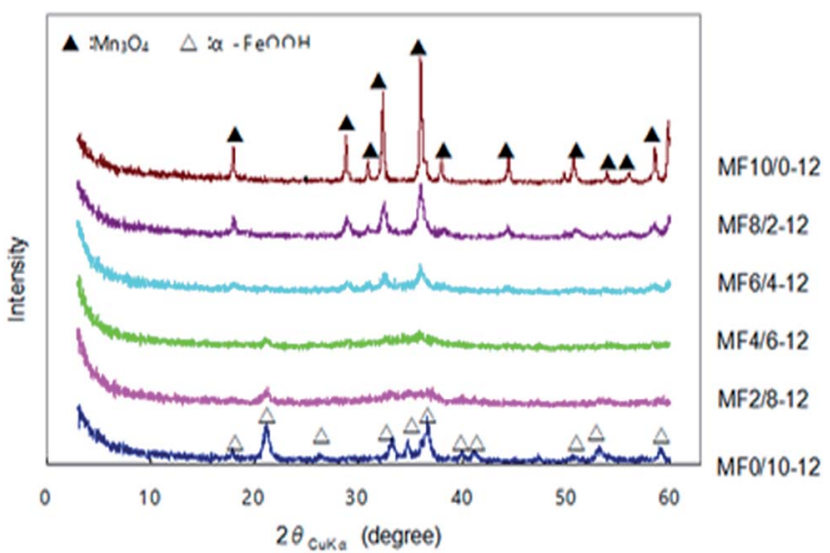

Fig. 1 XRD patterns of $\mathrm{Mn}$-Fe binary oxides prepared by reacting $\mathrm{Mn}(I)-\mathrm{Fe}(\mathrm{II})$ mixed solutions with different $\mathrm{Mn} / \mathrm{Fe}$ mole ratios and $\mathrm{NaOH}$ solution at $\mathrm{pH} 12$.

aggregates of particles with a size about $50 \mathrm{~nm}$. It contains a small amount of fibrous particles. Sample MF0/10-12 with $\alpha$ $\mathrm{FeOOH}$ phase consists of aggregates of rod-like particles. MF4/ 6-12 consists of particles with irregular shape and size, though most of the particles are not clearly observed due to its amorphous nature.

\section{As(III) adsorption on Mn-Fe binary oxide adsorbents}

A preliminary study of As(III) adsorption from a solution containing As(III) (20 $\mathrm{mg} \mathrm{L}^{-1}$ ) showed that the adsorption was fast enough to reach adsorption equilibrium by treatment for only
$4 \mathrm{~h}$. The As(III) removals by the adsorbents from a diluted solution containing $2 \mathrm{mg} \mathrm{L}^{-1} \mathrm{As}(\mathrm{III})$ are shown in Table 2 . All the adsorbents except for MF10/0-12 show good As(III) removals of above 99\%. The MF6/4-12, MF4/6-12 and MF2/8-12 samples can reduce the $\mathrm{As}(\mathrm{III})$ concentration from $2 \mathrm{mg} \mathrm{L}^{-1}$ to $2 \mu \mathrm{g} \mathrm{\textrm {L } ^ { - 1 }}$. After heat treatment at $350{ }^{\circ} \mathrm{C}$, the amorphous and low-crystalline samples (MF6/4-12, MF4/6-12, MF2/8-12) keep good As(III) removals (above 95\%), which is probably due to their large surface areas (Table 1).

The As(III) adsorptive ability of the Mn-Fe binary oxide adsorbents were compared with those of the conventional adsorbents. Three conventional iron oxide adsorbents, low- and high-crystalline akaganeite ( $\beta$-FeOOH, JCPDF 34-1266) and lowcrystalline schwertmannite $\left(\mathrm{Fe}_{8} \mathrm{O}_{8}(\mathrm{OH})_{8-2 x}\left(\mathrm{SO}_{4}\right) \cdot n \mathrm{H}_{2} \mathrm{O}\right.$, JCPDF 47-1775) were prepared. The As(III) removals increased in the order schwertmannite $(78.9 \%)<$ high crystalline $\beta$-FeOOH $(90.2 \%)<$ low crystalline $\beta$-FeOOH $(97.5 \%)$, which is in agreement with the results in the literature that low-crystalline $\beta$ FeOOH shows the highest arsenic removal. ${ }^{32}$ The MF6/4-12, MF4/6-12 and MF2/8-12 samples show the excellent As(III) removals of $99.9 \%$ when compared with the conventional iron oxides adsorbents.

The As(III) and As(v) removals from a concentrated solution (60 mg As per L) were studied using three kinds of adsorbents (Table 2). It is noticeable that the As(III) removals are nearly equal to the $\mathrm{As}(\mathrm{v})$ removals. The arsenic uptake increases in the order MF10/0-12 < MF0/10-12 < MF4/6-12, which correlates well with the order of the surface areas of the adsorbents. These results suggest that the As(III) and As(v) ions are adsorbed on the surface of the binary oxide adsorbent.
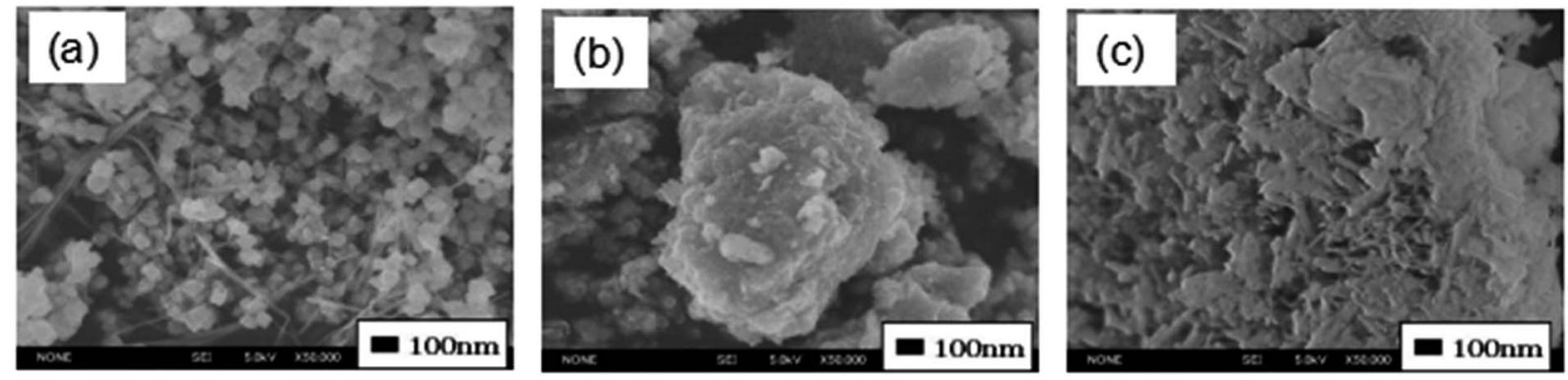

Fig. 2 SEM photographs of (a) MF10/0-12, (b) MF4/6-12 and (c) MF0/10-12 samples. 
Table 2 Arsenic adsorption results for $\mathrm{Mn}-\mathrm{Fe}$ binary adsorbents prepared using $\mathrm{NaOH}$ solution at $\mathrm{pH} 12$

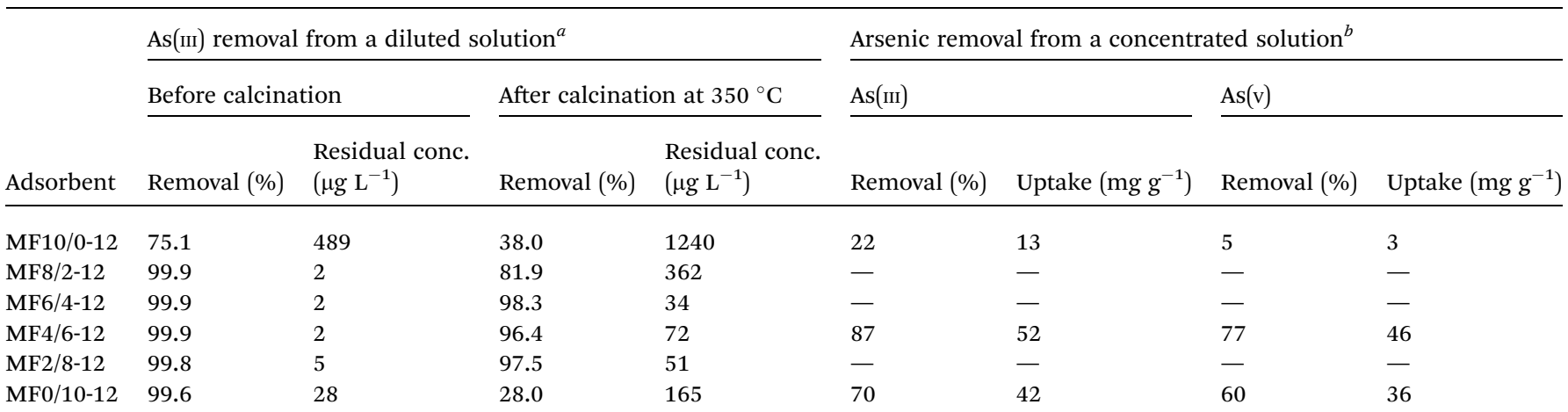

${ }^{a}$ Adsorbent: $25 \mathrm{mg}$; solution: $100 \mathrm{~mL}$; initial As(III) concentration: $2 \mathrm{mg} \mathrm{L}{ }^{-1}$; contact time: $22 \mathrm{~h} .{ }^{b}$ Adsorbent: $100 \mathrm{mg}$; solution: $100 \mathrm{~mL}$; initial arsenic concentration: $60 \mathrm{mg} \mathrm{L}^{-1}$; contact time: $22 \mathrm{~h}$.

\section{Kinetics study}

Adsorption rate is an important parameter in terms of As removal efficiency. Kinetics study of As(III) adsorption on MF6/412 at an initial concentration of $100 \mathrm{ppb}\left(100 \mu \mathrm{g} \mathrm{L}^{-1}\right)$ of arsenic stock solution has been investigated by a batch experiment. The process of As(III) removal is rapid and 5 min was required to remove $92 \%$, and equilibrium is reached after $120 \mathrm{~min}$. As(III) adsorption kinetics tests were carried out and two conventional kinetic models (pseudo-first-order and pseudo-second-order) were applied to analyse the experiment data. ${ }^{15,33}$

The pseudo-first-order model can be described as:

$$
\ln \left(q_{\mathrm{e}}-q_{t}\right)=\ln q_{\mathrm{e}}-k_{1} t
$$

where $q_{\mathrm{e}}$ and $q_{t}\left(\mu \mathrm{g} \mathrm{g}^{-1}\right)$ are the adsorbed As(III) amounts on at equilibrium and at various times $t$, respectively, and $k_{1}$ is the rate constant of the pseudo-first-order model of adsorption $\left(\min ^{-1}\right)$, the values of $q_{\mathrm{e}}$ and $k_{1}$ can be determined from the intercept and slop of the linear plot of versus $t$.

The pseudo-second-order model can be described as:

$$
\frac{t}{q_{t}}=\frac{1}{k_{2} q_{\mathrm{e}}^{2}}+\frac{t}{q_{\mathrm{e}}}
$$

where $q_{\mathrm{e}}$ and $q_{t}$ are defined as in the above pseudo-second-order model and $k_{2}\left(\mathrm{~g}(\mu \mathrm{g} \mathrm{min})^{-1}\right)$ is the rate constant of the pseudosecond-order model of adsorption, which can be obtained from the linear plot of $t / q_{t}$ versus $t$.

Fig. 3 presents the result of kinetic studies. The corresponding kinetic parameters and correlation coefficients are summarized in Table 3. The pseudo-second-order model with the correlation coefficient $R^{2}$ of 1 is found to be more suitable for fitting the kinetic data than the pseudo-first-order model with the correlation coefficient $R^{2}$ of 0.9688 , suggesting that the adsorption process might be chemisorptions. The experimental adsorption capacity is also in accordance with the calculated adsorption capacity obtained from the pseudo-second-order model.

\section{Dependence of arsenic removal on $\mathrm{pH}$ value of solution}

The effect of solution $\mathrm{pH}$ on arsenic adsorptive behavior was studied using MF4/6-12. The adsorbent $(25 \mathrm{mg})$ was added to

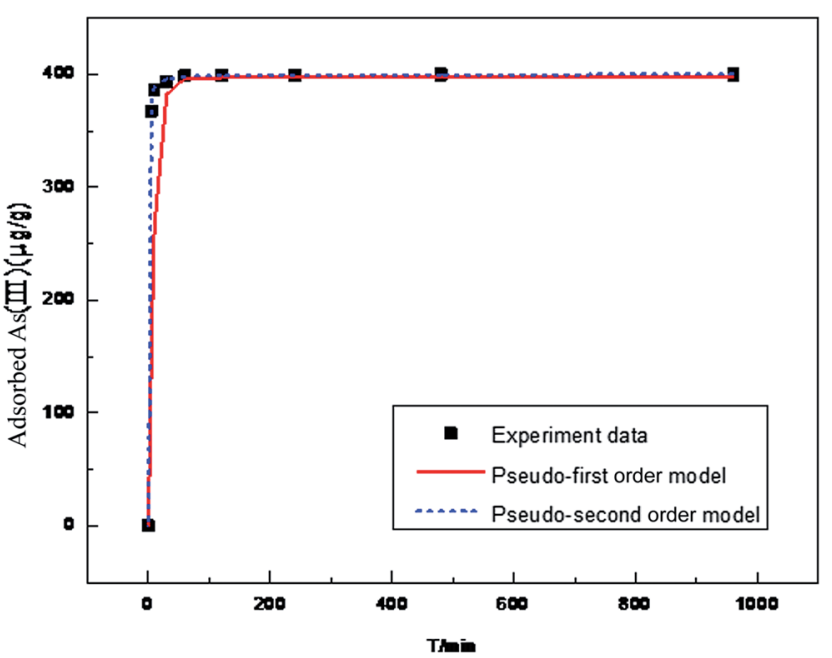

Fig. 3 Adsorption kinetics of As(III) on MF6/4-12 at room temperature (25 mg of MF6/4-12 in $100 \mathrm{~mL}$ of 100 ppb As(III) stock solution).

$\operatorname{As}(\mathrm{III})$ or As(v) solution $\left(2 \mathrm{mg} \mathrm{L}^{-1}, 100 \mathrm{~mL}\right)$ and stirred for $24 \mathrm{~h}$ at room temperature. The $\mathrm{pH}$ of arsenic solution was adjusted by $\mathrm{HCl}$ and $\mathrm{NaOH}$ solutions. The dependences of arsenic removals on the $\mathrm{pH}$ values of the solution are shown in Fig. 4. The removals at $\mathrm{pH}<7.5$ are nearly $100 \%$ with MF4/ 6-12 for both $\operatorname{As}(\mathrm{III})$ and $\mathrm{As}(\mathrm{V})$ and they decrease with increasing $\mathrm{pH}$ value in the region $\mathrm{pH}>8$. The similar trends with respect to $\mathrm{pH}$ suggest that parts of As(III) was oxidized to $\mathrm{As}(\mathrm{v})$ by this adsorbent. Zhang et al. reported that $\mathrm{Fe}-\mathrm{Mn}$ binary oxide with $\mathrm{Mn} / \mathrm{Fe}$ mole ratio of $1: 3$ showed $\mathrm{As}(\mathrm{v})$ removals of nearly $100 \%$ at $\mathrm{pH}<5.5$, and the removal decreased with increasing $\mathrm{pH}$ value in the region $\mathrm{pH}>6 .{ }^{27}$ Our study indicates that the MF4/6-12 should be more effective for the majority of water supplies, which normally have a $\mathrm{pH}$ range of $6.5-8.5 .^{34}$

Lower $\mathrm{pH}$ is favorable for the protonation of adsorbent surface, which increases the positively charged sites on the adsorbent surface, and enlarges the attraction force between the positively charged adsorbent surface and As anions, thus increases the adsorption ability of the adsorption in the lower 


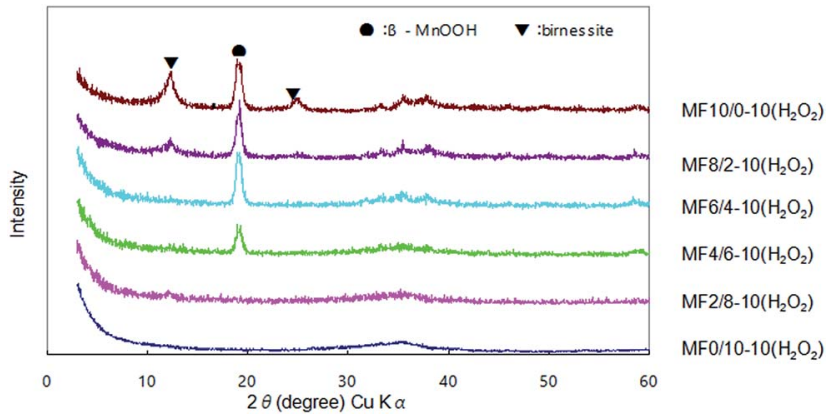

Fig. 6 XRD patterns of Mn-Fe binary oxides prepared by reacting $\mathrm{Mn}(\mathrm{II})-\mathrm{Fe}(\mathrm{II})$ mixed solutions with different $\mathrm{Mn} / \mathrm{Fe}$ mole ratios and $\mathrm{NaOH}$ solution containing $\mathrm{H}_{2} \mathrm{O}_{2}$ at $\mathrm{pH} 10$.

manganese oxide. We studied the precipitation of Mn-Fe binary oxide using a $\mathrm{NaOH}$ solution containing $\mathrm{H}_{2} \mathrm{O}_{2}$. The $\mathrm{As}$ (III) removals by the adsorbents prepared using the $\mathrm{NaOH}$ solutions containing $\mathrm{H}_{2} \mathrm{O}_{2}$ are summarized in Table 5. The As(III) removal depends on the precipitation $\mathrm{pH}$. It increases in the order MF6/
4-12 $\left(\mathrm{H}_{2} \mathrm{O}_{2}\right)<\mathrm{MF6} / 4-6.4\left(\mathrm{H}_{2} \mathrm{O}_{2}\right)<\mathrm{MF6} / 4-9.7\left(\mathrm{H}_{2} \mathrm{O}_{2}\right)$ for samples precipitated at $\mathrm{pH} 12,6.4$, and 9.7, respectively. The suitable precipitation $\mathrm{pH}$ is around 10 under the $\mathrm{H}_{2} \mathrm{O}_{2}$ oxidation conditions.

Therefore, the binary oxides with different $\mathrm{Mn} / \mathrm{Fe}$ mole ratios $(10 / 0,8 / 2,6 / 4,4 / 6,2 / 8$ and $0 / 10)$ were prepared at $\mathrm{pH} 10$. The XRD patterns of the adsorbents are shown in Fig. 6. Sample MF10/0-10 $\left(\mathrm{H}_{2} \mathrm{O}_{2}\right)$ prepared from pure $\mathrm{Mn}\left(\mathrm{NO}_{3}\right)_{2}$ is a mixture of $\beta-\mathrm{MnOOH}$ (JCPDF 18-0804) and birnessite (JCPDF 23-1046). The content of birnessite phase decreases rapidly with increasing $\mathrm{Fe}$ content in the adsorbent, while $\beta-\mathrm{MnOOH}$ phase remains even with increasing $\mathrm{Fe}$ content to $\mathrm{Mn} / \mathrm{Fe}=4 / 6\left(\mathrm{MF} 4 / 6-10\left(\mathrm{H}_{2} \mathrm{O}_{2}\right)\right)$. MF2/8-10 $\left(\mathrm{H}_{2} \mathrm{O}_{2}\right)$ and MF0/10-10 $\left(\mathrm{H}_{2} \mathrm{O}_{2}\right)$ samples are amorphous phase, which show a broad peak at around 35 degrees, suggesting the formation of ferrihydrite type iron hydroxide. ${ }^{37}$

Their As(III) adsorptive behaviors are similar to those prepared without $\mathrm{H}_{2} \mathrm{O}_{2}$ addition (Table 5). The MF10/0-10 $\left(\mathrm{H}_{2} \mathrm{O}_{2}\right)$ adsorbent without Fe addition exhibits low As(III) uptake, while the $\mathrm{Mn}-\mathrm{Fe}$ binary oxide adsorbents exhibit considerably high As(III) uptakes. The MF4/6-10 $\left(\mathrm{H}_{2} \mathrm{O}_{2}\right)$ adsorbent exhibits the most
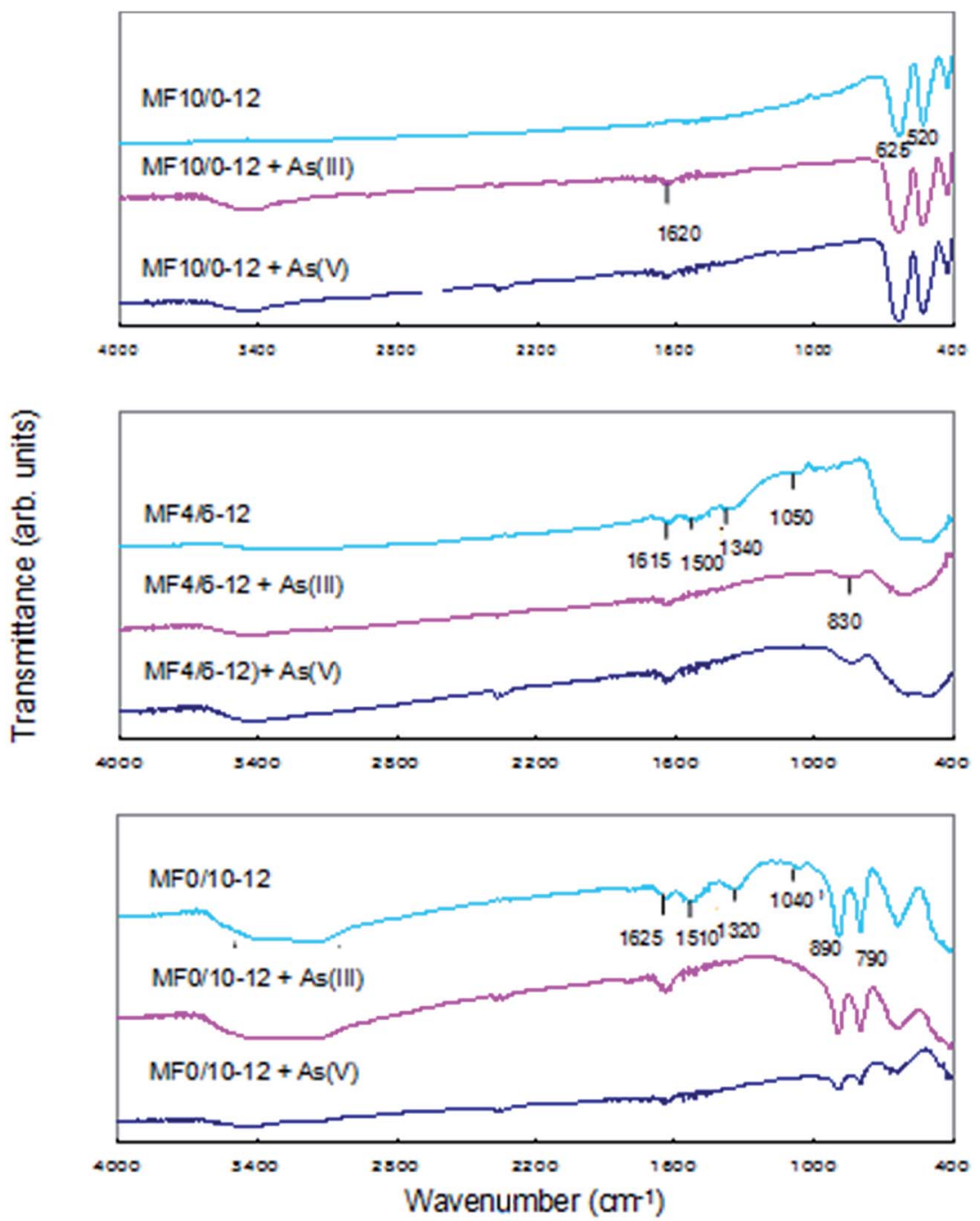

Fig. 7 FT-IR spectra of adsorbents before and after $\mathrm{As}(\mathrm{II})$ and $\mathrm{As}(\mathrm{V})$ adsorptions. 
excellent As(III) removal ability, reducing As(III) concentration to $2 \mu \mathrm{g} \mathrm{L}^{-1}$. The above results reveal that the $\mathrm{Mn}-\mathrm{Fe}$ binary oxides of amorphous and low-crystalline phases have high arsenic removal ability from a diluted solution.

\section{Mechanism of arsenic adsorption}

In order to clarify the adsorption mechanism, the physical and chemical analyses were carried out on the MF10/0-12, MF4/6-12 and MF0/10-12 samples before and after As(III) and $\operatorname{As}(\mathrm{v})$ adsorptions. Adsorbents (100 mg) were added into an As(III) or As(v) solution (60 mg As per L, $100 \mathrm{~mL}$ ) and stirred for $22 \mathrm{~h}$ at room temperature. The FT-IR spectra of the adsorbents before and after the arsenic adsorption are shown in Fig. 7. For MF0/ 10-12 with $\alpha$-FeOOH phase, the vibration bands at 1040, 1320 and $1510 \mathrm{~cm}^{-1}$ corresponding to $\mathrm{O}-\mathrm{H}$ bending vibration of $\mathrm{FeO}(\mathrm{OH})$ almost disappear by $\mathrm{As}(\mathrm{III})$ or $\mathrm{As}(\mathrm{v})$ adsorption. The bands at 890 and $790 \mathrm{~cm}^{-1}$, which can be ascribed to the lattice vibration of $\alpha-\mathrm{FeOOH}$, are rarely changed by the arsenic adsorption. This result indicates that arsenic is bound to the surface $\mathrm{OH}$ group of $\alpha$-FeOOH by a chelating reaction. ${ }^{38}$ The bands $\left(1500,1340\right.$, and $\left.1050 \mathrm{~cm}^{-1}\right)$ corresponding to the vibration of surface $\mathrm{OH}$ group are also observed in the spectrum of MF4/6-12 although it has amorphous phase but not $\alpha$-FeOOH phase. The bands disappear by the arsenic adsorption, suggesting that the $\mathrm{OH}$ group on the surface of binary oxide involves the arsenic adsorption similar to the case of $\alpha-\mathrm{FeOOH}$. These bands are not observed in the spectrum of MF10/0-12 with $\mathrm{Mn}_{3} \mathrm{O}_{4}$ phase, whose FT-IR pattern does not change obviously by arsenic adsorption. The formation of $\mathrm{OH}$ group on the adsorbent surface is an important factor for the effective adsorption of arsenic.

The change in $\mathrm{Mn}$ valence after arsenic adsorption was investigated using MF4/6-12. The As(III) and As(v) uptakes are 52 and $46 \mathrm{mg}$ As per g, respectively, as shown in Table 2. The Mn valence decreased significantly from 3.39 to 2.99 after As(III) adsorption, suggesting that oxidation of As(III) to As(v) took place during the adsorption, accompanied by the reduction of $\mathrm{Mn}$ (IV) to Mn(III). The decrease of Mn valence is small (from 3.39 to 3.27) in the case of As(v) adsorption. Moore et al. and Nesbitt et al. demonstrated that the oxidation of As(III) by the synthetic birnessite surface proceeds by two step pathway (reaction (5) and (6) as follows), involving the reduction of $\mathrm{Mn}$ (Iv) to $\mathrm{Mn}$ (III) and then $\mathrm{Mn}$ (III) to $\mathrm{Mn}$ (II). ${ }^{39,40}$

$$
\begin{gathered}
2 \mathrm{MnO}_{2}+\mathrm{H}_{3} \mathrm{AsO}_{3}=2 \mathrm{MnOOH}^{*}+\mathrm{H}_{3} \mathrm{AsO}_{4} \\
2 \mathrm{MnOOH}^{*}+\mathrm{H}_{3} \mathrm{AsO}_{3}+4 \mathrm{H}^{+}=2 \mathrm{Mn}^{2+}+\mathrm{H}_{3} \mathrm{AsO}_{4}+3 \mathrm{H}_{2} \mathrm{O}
\end{gathered}
$$

We can conclude from the above results that the adsorption of As(III) on binary oxide progresses via the oxidation to As(v) followed by the chelating reaction with surface $\mathrm{OH}$ groups. Manganese species in the binary oxide accelerates the oxidation of $\operatorname{As}(\mathrm{III})$ to $\operatorname{As}(\mathrm{v})$. Since As(III) is adsorbed after oxidation to As(v), its adsorption site may be the same as that for As(v).

The arsenic removal of real water sample which contains many competitive ion such as $\mathrm{SO}_{4}{ }^{2-}, \mathrm{CO}_{3}{ }^{2-}, \mathrm{SiO}_{4}{ }^{2-}, \mathrm{PO}_{4}{ }^{3-}$ and humic acid by $\mathrm{Mn}-\mathrm{Fe}$ binary oxide adsorbents have been reported by literatures. ${ }^{15,27}$ Phosphate whose molecular structure is very similar to arsenic ion was the greatest competitor with arsenic for adsorptive sites on the adsorbent. The adsorbent follows the selectivity pattern $\mathrm{PO}_{4}{ }^{3-}>\mathrm{SiO}_{4}{ }^{2-}>\mathrm{CO}_{3}{ }^{2-}>$ $\mathrm{SO}_{4}{ }^{2-}$ and the sulfate and humic acid have no significant effect on arsenic removal.

\section{Conclusions}

Mn-Fe binary oxides prepared by alkaline hydrolysis of a mixed solution of $\mathrm{Mn}\left(\mathrm{NO}_{3}\right)_{3}$ and $\mathrm{Fe}_{2}\left(\mathrm{NO}_{3}\right)_{3}$ show good adsorption ability for both As(III) and As(v) in a diluted solution. The binary oxide with amorphous or low-crystalline phases exhibits the high arsenic removal ability due to its large surface area. MF4/6$10\left(\mathrm{H}_{2} \mathrm{O}_{2}\right)$ with a mixture of $\beta-\mathrm{MnOOH}$ and amorphous iron hydroxide exhibits the most excellent As(III) removal of $99.9 \%$ at $\mathrm{pH}<7.5$, reducing As(III) concentration to $2 \mu \mathrm{g} \mathrm{L}^{-1}$, which clears the arsenic limit of $10 \mu \mathrm{g} \mathrm{L}^{-1}$ in drinking water by the WHO. Manganese species in the binary oxide accelerates oxidation of As(III) to As(v), which enhances As(III) adsorption ability of the adsorbent. Iron species in the binary oxide has a role to form surface $\mathrm{OH}$ groups, which is an important factor for the effective adsorption of As(v) by surface chelating reaction.

\section{Acknowledgements}

This study was supported by the Natural Science Foundation of China (No. 21266014), and Grant-in-Aid for Science Research (B) (No. 26289240) from the Japan Society for the Promotion of science.

\section{References}

1 D. Mohan and C. U. Pittman Jr, J. Hazard. Mater., 2007, 142, 1.

2 X. C. Le, S. Yalcin and M. S. Ma, Environ. Sci. Technol., 2000, 34, 2342.

3 W. R. Cullen and K. J. Reimer, Chem. Rev., 1989, 89, 713.

4 P. L. Smedley and D. G. Kinniburgh, Appl. Geochem., 2002, 17, 517.

5 J. F. Ferguson and J. Gavis, Water Res., 1972, 6, 1259.

6 W. R. Penrose, CRC Crit. Rev. Environ. Control, 1974, 4, 465.

7 L. G. Roberts, S. J. Hug, T. Ruettimann, A. W. Khan and

M. T. Rahman, Environ. Sci. Technol., 2004, 38, 307.

8 D. R. Borum and C. O. Abernathy, in Arsenic exposure and health effects, Science and Technology Letter, Nothwood, U. K., 1994, p. 21.

9 S. Goldberg and R. Johnston, J. Colloid Interface Sci., 2001, 234, 204.

10 T. R. Holm, J. Am. Water Works Assoc., 2002, 94, 174.

11 L. S. McNeill and M. Edwards, J. Am. Water Works Assoc., 1997, 89, 75.

12 J. J. Waypa, M. Elimelech and J. G. Hering, J. Am. Water Works Assoc., 1997, 89, 102.

13 P. Brandhuber and G. Amy, Desalination, 1998, 117, 1.

14 L. S. Thakur and P. Mondal, Desalin. Water Treat., 2016, 117. 
15 D. Ociński, I. Jacukowicz-Sobala, P. Mazur, J. Raczyk and E. Kociołek-Balawejder, Chem. Eng. J., 2016, 294, 210.

16 S. E. O'Relly, D. G. Strawn and D. L. Sparks, Soil Sci. Soc. Am. J., 2001, 6, 67.

17 L. Dambies, Sep. Sci. Technol., 2004, 39, 603.

18 P. Mondal, C. B. Majumder and B. Mohanty, J. Hazard. Mater., 2008, 150, 695.

19 P. Mondal, C. B. Majumder and B. Mohanty, J. Hazard. Mater., 2007, 144, 420.

20 P. Mondal, B. Mohanty, C. B. Majumder and N. Bhandari, AIChE J., 2009, 55, 1860.

21 P. Mondal, C. Balomajumder and B. Mohanty, Clean: Soil, Air, Water, 2007, 35, 255.

22 E. A. Deliyanni, D. N. Bakoyannakis, A. I. Zouboulis and K. A. Matis, Chemosphere, 2003, 50, 155.

23 Z. M. Gu, J. Fang and B. L. Deng, Environ. Sci. Technol., 2005, 39, 3833.

24 Alcan Chemicals, Product data, AAFS-50, ALCAN Chemicals, Montreal, Canada, 1998.

25 M. Jang, S. H. Min, T. H. Kim and J. K. Park, Environ. Sci. Technol., 2006, 40, 1636.

26 D. W. Oscarson, P. M. Huang and U. T. Hammer, Water, Air, Soil Pollut., 1983, 20, 233.

27 G. S. Zhang, H. J. Liu, J. H. Qu and W. Jefferson, J. Colloid Interface Sci., 2012, 366, 141.
28 R. Chitrakar, S. Tezuka, A. Sonoda, K. Sakane, K. Ooi and T. Hirotsu, J. Colloid Interface Sci., 2006, 298, 602.

29 R. Chitrakar, S. Tezuka, A. Sonoda, K. Sakane and T. Hirotsu, Ind. Eng. Chem. Res., 2009, 48, 2107.

30 J.-Y. Yu, M. Park and J. Kim, Geochem. J., 2002, 36, 119.

31 S. Saracoglu, M. Soylak and L. Elci, Acta Chim. Slov., 2003, 50, 807.

32 S. Dixit and J. G. Hering, Environ. Sci. Technol., 2003, 37, 4182.

33 G. S. Zhang, J. Y. Qi and H. N. Li, Bioresour. Technol., 2015, 193, 273.

34 Z. Gu, J. Fang and B. L. Deng, Environ. Sci. Technol., 2005, 39, 3833.

35 G. S. Zhang, J. H. Qu, H. J. Liu, R. P. Liu and R. C. Wu, Water Res., 2007, 41, 1921.

36 I. Jacukowicz-Sobala, D. Ocinski and E. Kociolek-Balawejder, Ind. Eng. Chem. Res., 2013, 52, 6453.

37 P. J. Swedlund and J. G. Webster, Water Res., 1999, 33, 3413. 38 G. S. Zhang, F. D. Liu, H. J. Liu, J. H. Qu and R. P. Liu, Environ. Sci. Technol., 2014, 48, 10316.

39 H. W. Nesbitt, G. W. Canning and G. M. Bancroft, Geochim. Cosmochim. Acta, 1998, 62, 2097.

40 J. N. Moore, J. R. Walker and T. H. Hayes, Water Res., 2007, 41, 1921. 